$0.5 \mathrm{mg} \mathrm{MnO}_{2}$ produced $0.65 \mathrm{mg}$ purpurogallin

$\begin{array}{rlll}5.0 \mathrm{mg} & & , & 1.15 \mathrm{mg} . \quad \\ 50.0 \mathrm{mg} \quad, & , & 4.65 \mathrm{mg} \quad,\end{array}$

$\mathrm{MnO}_{2}$ produces purpurogallin from pyrogallic acid without the co-operation of $\mathrm{H}_{2} \mathrm{O}_{2}$ but only in very small amounts. For example, $50 \mathrm{mg} \mathrm{MnO}_{2}$ produced in 10 minutes $4.6 \mathrm{mg}$ purpurogallin in the presence of $\mathrm{H}_{2} \mathrm{O}_{2}$, and only $0.6 \mathrm{mg}$ without the aid of $\mathrm{H}_{2} \mathrm{O}_{2}$. The addition of $\mathrm{H}_{2} \mathrm{O}_{2}$ alone to pyrogallic acid solution gave rise to no appreciable amount of purpurogallin within the same duration of time. As well known a certain small amount of purpurogallin is produced when pyrogallic acid solution is left exposed to the air. Apparently $\mathrm{MnO}_{2}$ accelerates to some extent this simple oxidative process, in addition to possessing the marked peroxidase action, which is revealed in the presence of $\mathrm{H}_{2} \mathrm{O}_{2}$.

We made no attempt to work out the mode of the peroxidase action of $\mathrm{MnO}_{2}$. It may be mentioned in passing, without giving experimental details, that unlike the action of the true peroxidase, the peroxidase activity of $\mathrm{MnO}_{2}$ is not influenced by hydrogen ion concentration within the range of $\mathrm{pH}$ 1.8-9.4. On the other hand certain known inhibitors of the true peroxidase inhibit the action of $\mathrm{MnO}_{2}$ also. These inhibitors are $\mathrm{KCN}, \mathrm{HgCl}_{2}$, $\mathrm{NH}_{2}(\mathrm{OH}) \mathrm{HCl}$, and phenylglyoxime. ' $\mathrm{KClO}$ fails to produce any inhibition.

\title{
SUMMARY
}

$\mathrm{MnO}_{2}$ was placed on record as an "Inorganic peroxidase" per excellence, and some aspects of its activity were discussed. $\mathrm{MnO}_{2}$ has long been known to possess a strong "catalase activity", so that one and the same substance has now been demonstrated to exhibit the actions of two different enzymes. $\mathrm{PbO}_{2}$, another example of "inorganic catalase", is devoid of peroxidase action.

The author wishes to express her appreciation to Dr. Waro Nakahara, under whose guidance the present experiments were carried out.

\section{ON THE CHEMISTRY OF VITAMIN $B_{6}{ }^{*}$}

\author{
By Akryoshi ICHIBA \\ Scientific Research Institute (Formerly the Institute \\ of Physical and Chemical Research), Tokyo
}

Within the last few years we have seen a revival of interest in the study of vitamin $\mathrm{B}_{6}$ from biological rather than chemical standpoint; much work is now being done on the metabolite of this vitamin and its relation to the metabolism of protein and to enzyme systems. Of particular interest are the recent works of Snell et al. and Gunsalus, Bellamy and Umbereit (1).

* Dedicated to the memory of the late Prof. U. Suzuki 
With respect to the chemical nature of this vitamin, however, there remain no details yet to be cleared up. It may not be without significance, therefore, to look upon the progress of investigations made during the last few years.

It is especially desired to stress the remarkable progress in this field during the years from 1938 to 1940, during which period, the isolation, the structural elucidation, and the synthesis of this vitamin were accomplished in quick succession. Our present knowledge of the chemical nature of this vitamin we owe mainly to Kuhn et al. (2) and American workers (3), especially Harris and Folkers. The contributions of major significance by them must be praised. We also made independently attempts to gain proper understanding of the chemical aspect and made some valuable contributions along this line.

It is not our purpose here to give a full description of all the worthy works that have appeared and to assess the relative merits of so many contributions. In this short review we consider it advisable to mention our results so far obtained in their relation to the work of others.

Almost simultaneously and independently crystalline vitamin $B_{6}$ was obtained in a number of laboratories $(2,3,5,6)$ in the year 1938 and, moreover, there was a good agreement concerning the chemical composition and biological assay of the product isolated. Rats were cured of dermatitis and resumed growth when fed $5 r$ to $10 r$ of the hydrochloride per day. As far back as 1931 Ohdake, (7) working with U. Suzuki, had isolated a crude preparation of this substance from which pure vitamin $B_{6}$ was readily obtained. Ohdake was aheads of his time since the technique for the biological recognition of vitamin $B_{6}$ had not yet been developed.

Our method of isolation (5) deviated somewhat from those applied by others inasmuch as an adsorption on charcoal and elution with alcohol and then with ammoniacal aqueous acetone was introduced prior to the final precipitation with mercuric chloride or phosphotungstic acid.

The accepted formula for the hydrochloride was $\mathrm{C}_{8} \mathrm{H}_{10} \mathrm{O}_{3} \mathrm{~N} . \mathrm{HCl} \mathrm{mp} .209-210^{\circ} \mathrm{C}$ (dec.).

The free base mp. $154-5^{\circ} \mathrm{C}$ was optically inactive, contained neither- $\mathrm{OCH}_{3}$ nor: $\mathrm{NCH}_{3}$ residues and gave a deep red color with aqueous ferric chloride, indicating the presence of a phenolic hydroxyl group. And our crystalline hydrochloride showed defined absorption bands at 327,293 and $246 \mathrm{~m}$ in $10^{-3} \mathrm{~mol}$ aqueous solution (5b).

To secure some knowledge on the function of oxygen atoms in molecule, we prepared triacetyl, tribenzoyl, and monomethyl derivatives; $\mathrm{C}_{8} \mathrm{H}_{8} \mathrm{NO}_{3}\left(\mathrm{COCH}_{3}\right)_{3}$ viscous oil, $\mathrm{C}_{8} \mathrm{H}_{8} \mathrm{NO}_{3}$ $\left(\mathrm{COC}_{6} \mathrm{H}_{5}\right)_{3} \mathrm{mp} .121-122^{\circ} \mathrm{C}$ and $\mathrm{C}_{8} \mathrm{H}_{10} \mathrm{NO}_{2}\left(\mathrm{OCH}_{3}\right)$ mp. $103-105^{\circ} \mathrm{C}$ respectively $(5 \mathrm{c})$.

Special attention was called to the fact that by the methylation with diazomethan we obtained, in addition to monomethyl ether a reaction product which was $\mathrm{N}$-methyl derivative, isomeric to the $\mathrm{C}$-methyl derivative (5d).

On the basis of this fact and on other observations on the zinc dust distillation, we were inclined to make a hasty conclusion, without full consideration of phenol betain as described by R. R. Williams (8), that the enolic hydroxyl in the vitamin molecule might be of 2-or 4-position of pyridine. 
Just as we made these observations we received the valuable paper by R. Kuhn and G. Wendt, dealing with the functional groups is the vitamin molecule (2c). They skillfully demonstrated that all three oxygen atoms in the molecule exist in the form of hydroxyl and the nitrogen atom is evidently "ringtertiar" on the basis of the formation of the monomethyl and diacetylmonomethyl derivatives and of no evolution of methane even at higher temperature at the determination of active hydrgen in the latter. Furthermore the fact that the base was of tertiary cyclic nature and gave a deep blue color with Folin-Denis reagent, similar to that produced by $\beta$-hydroxypyridine, led them to a comparison of the vitamin with $\beta$-hydroxypyridine and its derivatives. Shortly afterwards Kerestztesy and his co-workers published the same observations.

In fact, with the isolation of vitamin $B_{6}$ there followed almost immediately communications on the chemical structure of this vitamin. Kuhn et al., in a series of publications $(2 \mathrm{~d}, \mathrm{e}, \mathrm{f})$ showed that the formula for vitamin $\mathrm{B}_{\mathrm{r}}$ is<smiles>CC1=C(O)C(CO)=C(CO)[CH+]=N1</smiles>

Independent confirmation for this structure was quickly forthcoming both from us and from the American workers. Our attempt to clear up this subject had been made by a careful oxidative degradation ( $5 \mathrm{~d}, \mathrm{e})$; Two products, one neutral, mp. 105-107 of presumable formula $\mathrm{C}_{9} \mathrm{H}_{9} \mathrm{NO}_{3}$, and the other, dicarboxylic, mp. $217-219^{\circ} \mathrm{C}$ (dec.) of $\mathrm{C}_{9} \mathrm{H}_{9} \mathrm{NO}_{5}$, we obtained so far in the oxidation of monomethyl ether of vitamin with potassium permanganate in alkaline medium.

Kuhn and his co-workers obtained by oxidation substances having formula, $\mathrm{C}_{9} \mathrm{H}_{9} \mathrm{NO}_{3}$, $\mathrm{C}_{9} \mathrm{H}_{9} \mathrm{NO}_{5}$ and $\mathrm{C}_{9} \mathrm{H}_{7} \mathrm{NO}_{7}$, first two of which we had already obtained. Furthermore, they obtáined, by the anhydrid formation of the latter two, $\mathrm{C}_{9} \mathrm{H}_{7} \mathrm{NO}_{4}$ and $\mathrm{C}_{8} \mathrm{H}_{5} \mathrm{NO}_{4}$ respectively, and established the constitution of these anhydrides to be 2-methyl-3-methoxypyridin dicarboxylic $(4,5)$ acid anhydride and 3-methoxypyridindicarboxylic $(4,5)$ acid anhydride. Thus the chemical constitution of the vitamin was elucidated by them to be 3-hydro 4 , 5 bis (hydroxymethyl)-2-methylpyridin above cited. (2f)

One of the grounds, upon which their work was based, was the synthetical elucidation that the dicarboxylic substance $\mathrm{C}_{9} \mathrm{H}_{9} \mathrm{NO}_{5}$ was 2-methyl-3-methoxypyridin dicarboxylic acid $(4,5)$ but so far they gave no detailed imformation on its synthesis.

For the purpose of the identification of the compound $\mathrm{C}_{9} \mathrm{H}_{9} \mathrm{NO}_{5}$, we made attempts at the synthesis of 2-methyl-3-methoxypyridin dicarboxylic acid $(4,5)$. (5e)

The method we used was first to prepare 2-methyl-3-methoxy-1-chlorisoquinoline according to Gabriel and Colman, then to reduce it to 2-methyl-3-methoxy-isoquinoline with tin and hydrochloric acid, and finally to obtain the desired substance by oxidation with potassium permanganate. $(5 \mathrm{e})$

The mixed melting point of this compound with the substance $\mathrm{C}_{9} \mathrm{H}_{9} \mathrm{NO}_{5}$ derived from 
O-methyl vitamin, gave no depression. Thus we were able to synthesize the substance $\mathrm{C}_{9} \mathrm{H}_{9} \mathrm{NO}_{5}$ and confirm the constitutional formela of vitamin $\mathrm{B}_{6}$ proposed by $\mathrm{Kuhn}$ and his coworkers $(5 \mathrm{e})$.

The scheme of synthesis is outlined in the following diagram.

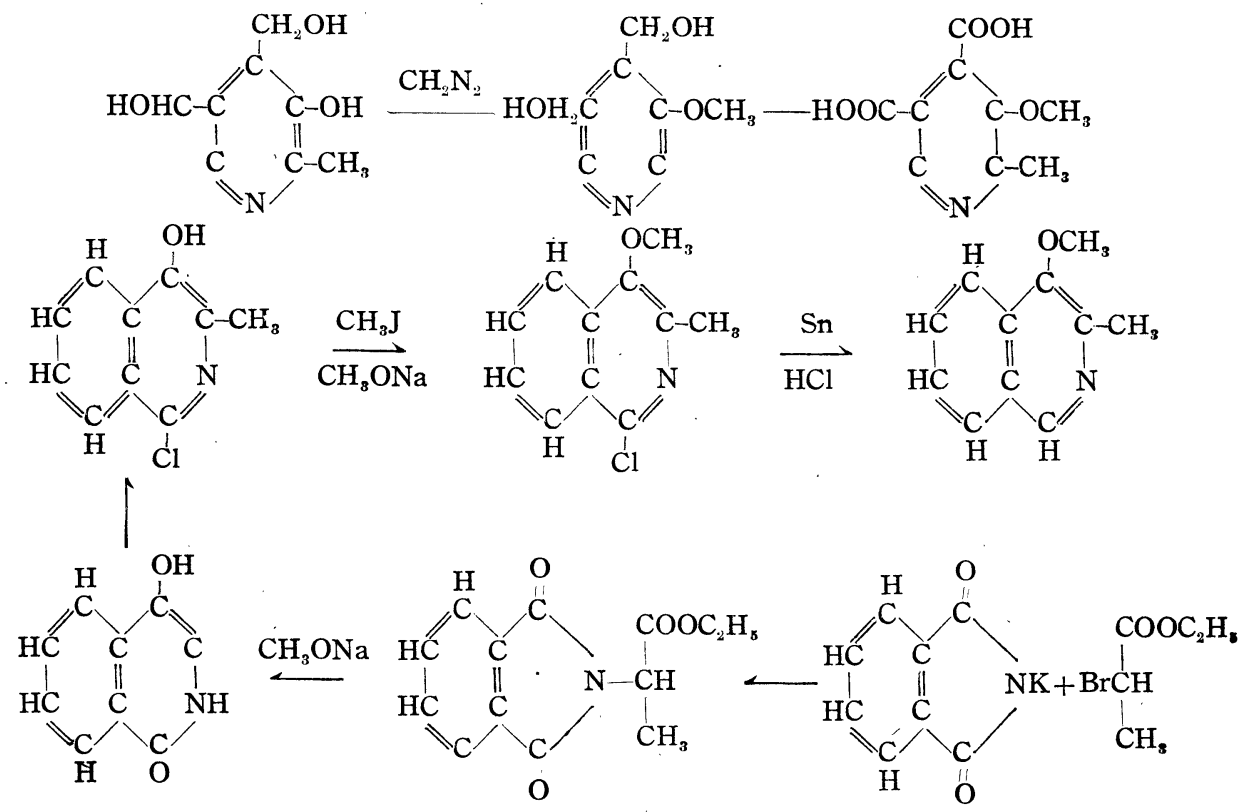

A most convincing proof, however, for the essential correctness of the structure for vitamin $B_{6}$ has evolved from its synthesis.

With the outstanding success in the elucidation of chemical structure, the attentions. of workers in this field have been fixed to total synthesis of vitamin $B_{8}$.

It may be natural that the procedures proposed for synthesis of the degradation product, 2-methoxy-pyridin dicarboxylic acid $(4,5)$, should lead directly to the way: of synthesizing the vitamin itself.

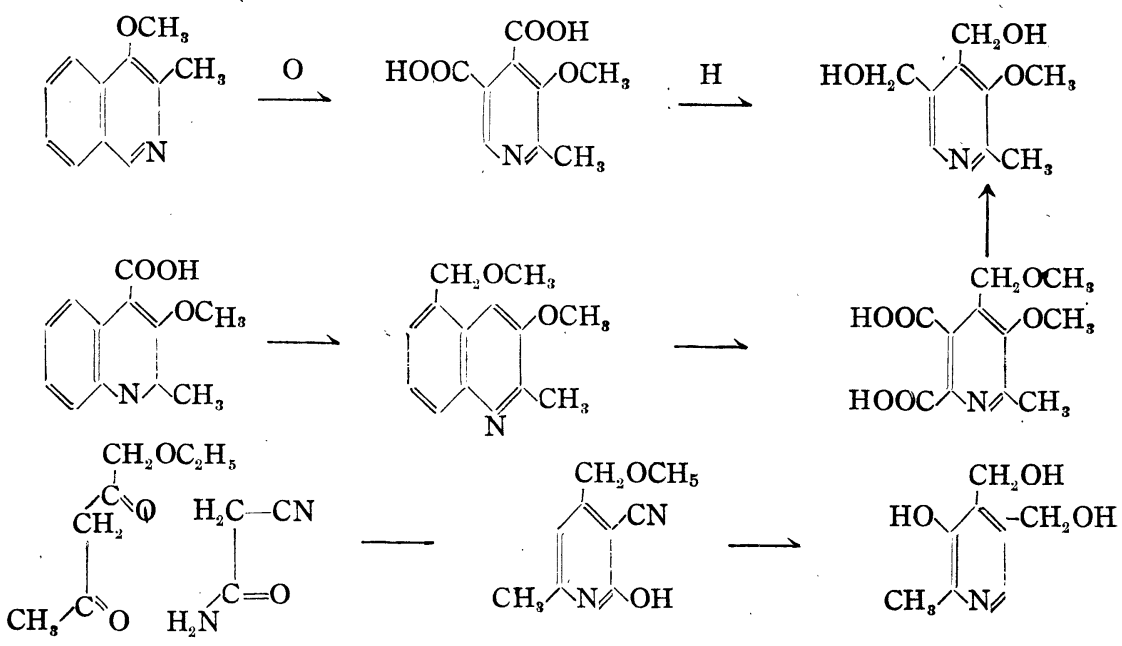


As the most promising route for the vitamin synthesis, 2-methyl pyridine substituted with suitable precursor of hydroxymethyl group in the position 4 and 5 seemed to be available. In this connection, the feasible methods fall into two groups; one, 2-methyl3-methoxy-pyridine dicarboxylic acid by way of isoquinoline or quinoline derivatives and the other, suitably substituted 2 -methyl pyridine through condensing $a$ - $\gamma$-diketon with cyanoacetic ester.

Our first attempt to synthesize vitamin $B_{6}$ was to obtain it reductively from 2-methyl3 -methoxy pyridine dicarboxylic acid $(4,5)$, the oxidative degradation product of $\mathrm{B}_{\mathrm{b}}$ methylether (above cited). This had been successfully accomplished by R. Kuhn and his co-workers, when our work was still in progress and there were several details yet to be cleard up. $(2 \mathrm{i}, 5 \mathrm{~g})$<smiles>COc1c(C)ncc2c1CCCC2</smiles>

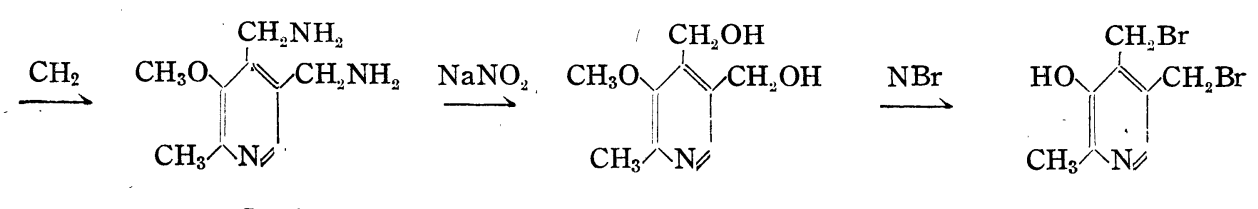<smiles>Cc1nnc(CO)c(O)c1CO</smiles>

In the course of our study in this line, we met with a difficulty in the preparation of the corresponding acid amide of 2-methyl-3-methoxy cinchomeronic acid by the usual established method, which involved esterification with alcoholic hydrochloric acid and subsequent conversion to acid amide with alcoholic ammonia.

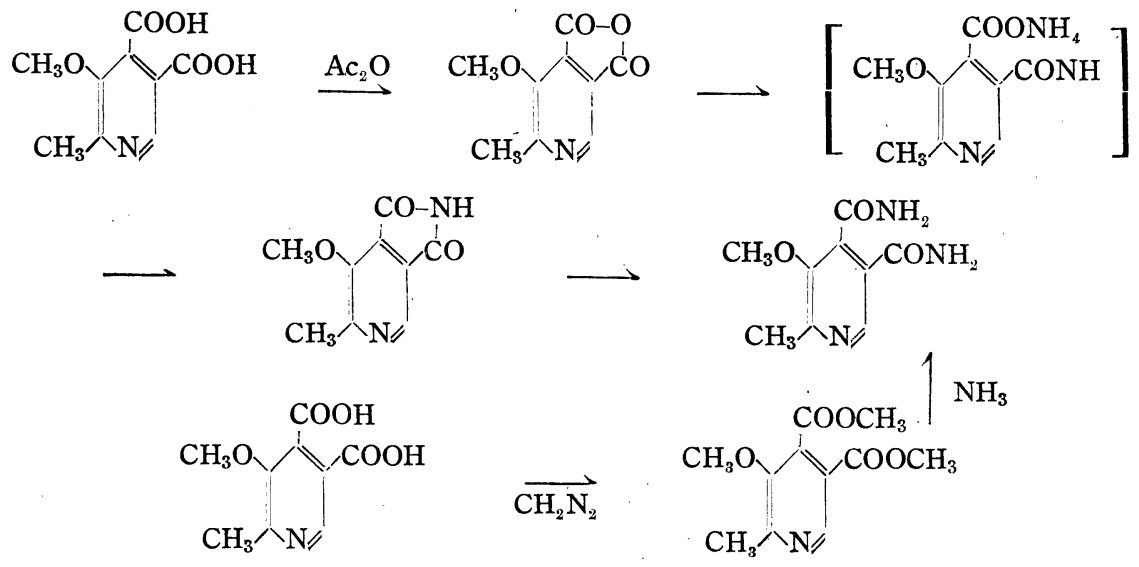

We therefore fell back on two other methods for the same purpose. One of these methods consisted of the preparation of the desired di-ester with diazomethan from 2methyl-3-methoxy pyridine dicarboxylic acid $(4,5)$. The other process involved first the 
production of acid anhydride of dicarboxylic acid which was transformed to imide and then to acid amide. Both of these methods yielded identical amide mp. 209-210 $\mathrm{C}$. with decomposition.

Formerly Bardham (9) and also Simonsen and Nyak (10) described the synthesis of 3-cyano-4, 6-dimethyl-2-pyridone by condensation of acethylacetone and cyanoacetic amide.

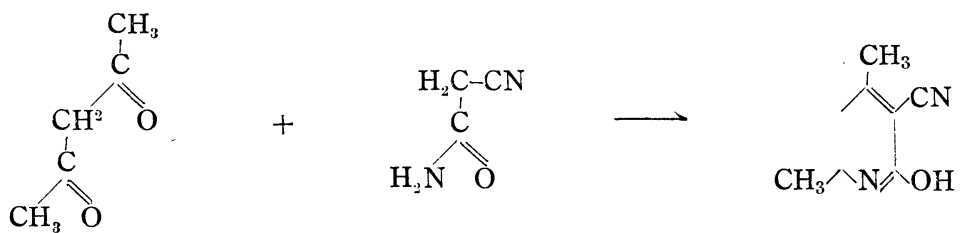

The chemistry of 2-pyridone has long been a subject of great interest in the preparation of pharmaceuticals and it has gained still greater prominence since the advent of vitamin $B_{i}$. In the synthesis of 2-pyridone, the pyridine ring system is frequently synthesized from suitable aliphatic compounds.

Harris and Folkers adopted this principle and accomplished their meritorious synthesis of the vitamin $(4 \mathrm{C})$. Their procedure consisted in the reaction of cyanoacetamide and ethoxyacetylacetone leading to the formation of 3-cyano-4-ethoxymethyl-6-methyl-2pyridone.

Theoretically the condensation can also occur in an alternative way illustrated by the equation.<smiles>CCOCC(=O)CC(C)=O</smiles>

The mechanism of the reaction has been studied by Bardham with cyanoacetamide and several 1, 3 diketones. He produced evidence that formation of the pyridine derivatives procceds through unsaturated intermediates as illustrated by the scheme.

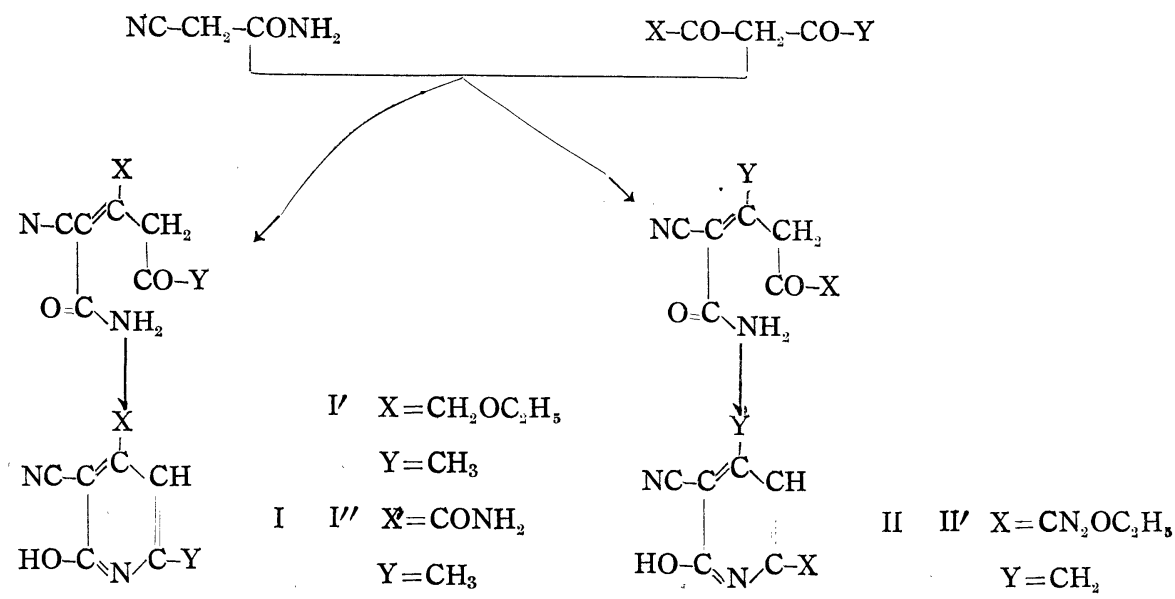


He postulated that the relative reactivity of the respective carbonyl group will determine the proportion of I and II in the condensation product. The predominant isomer will have I, if the carbonyl group adjacent to group $\mathrm{X}$ is more reactive and formula II if the more reactive carbonyl group is adjacent to $\mathrm{Y}$.

In the reaction of ethoxyacetone with cyanoacetamide both possible compounds $\mathrm{I}^{\prime}$ and II are formed. If instead of ethoxyacetylacetone the acetopyruvic acid amide $\mathrm{CH}_{3} \mathrm{COCH}_{2} \mathrm{CO}$ $\mathrm{CONH}_{2}$ is used, the isomer $\mathrm{I}^{\prime \prime}$ is predominant.

The process of Harris and Folkers was employed which involved condensing ethoxyacetylacetone with cyanoacetamide in the presence of piperidine in $95 \%$ ethylalcohol to form 3-cyano-4-ethoxymethyl-6-methyl-2-pyridone, treating the latter compound with nitric acid to form 3-cyano-4-ethoxymethyl-5-nitro-6-methyl-2-pyridone, chlorinating the latter to 2-chlopyridine, reducing the latter to 5-amino-3, 4-bisaminomethyl compound, diazotizing the latter to the vitamin.<smiles>CCOCC(=O)CC(C)=O</smiles>

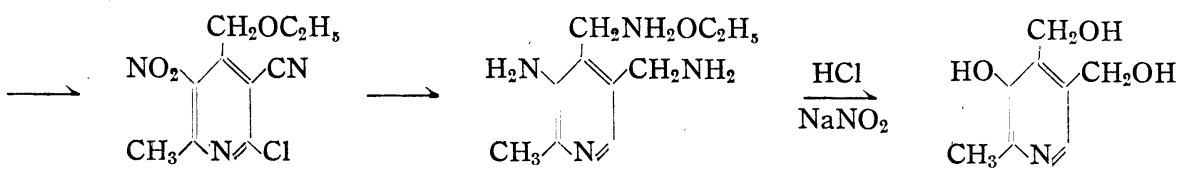

In view of our first attempt being through the vicinal dicyano compound as an intermediate and, moreover, the latter being easily synthesized as compared with the corresponding alkoxymethyl cyano compound which was used by Harris and Folkers, our second method of synthesis (5h) consisted of a series of the processes described below :-<smiles>CC(=O)CC(=O)C(N)=O</smiles>

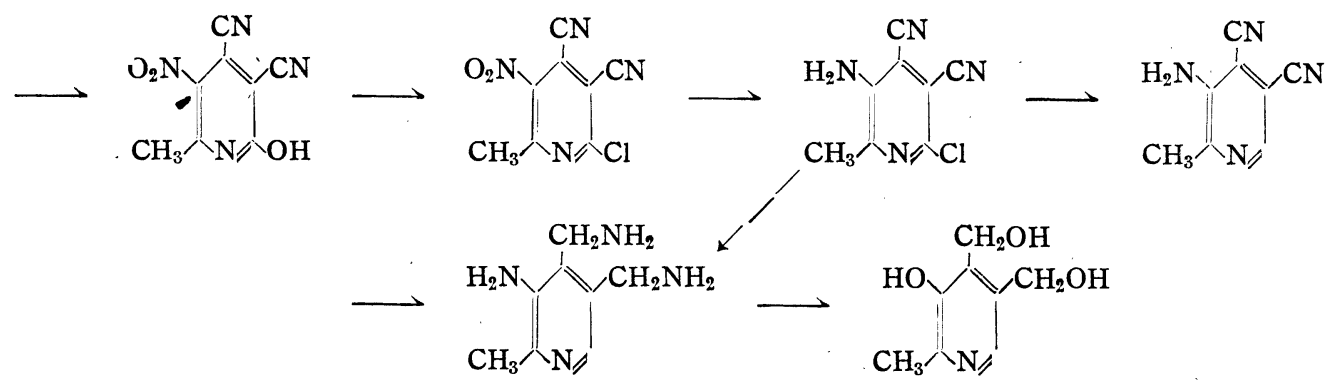


We employed the process which involved condensing acetopyruvic amide with cyanoacetamide in the presence of diethylamine to form the amide of 3-cyano-4-carboxy-6methyl-2-pyridone, which was dehydrated to 3, 4-bis (dicyano)-6-methyl-2-pyridine. This product was nitrated to form 5 -nitrocompound which, by halogenation with phosphorpentachloride and phosphoroxychloride, was converted to 2-chlor-3, 4-bis (cyano)-5nitro-6-methylpyridine. The latter compound was partially reduced with titantrichloride to give 2-methyl-3-amino-4, 5, bis cyano pyridine and by the subsequent reduction with palladium bariumcarbonate, dehalogenated to form 4,5 bis cyano 3-amino-2-methylpyridine. This compound was subjected to a more complete reduction to give 2-methyl-3amino-4, 5 bis (aminomethyl)-pyridine, which, on diazotizing, gave vitamin B hydrochloride.

In the recent publication on the vitamin synthesis almost similar procedures to ours was reported by J, H. Mowat, F. J. Pilgrim and G. H. Carlson (11). It is especially desired, however, to stress the more profitable procedures adopted by us in the dehydration of acid amide to nitrile $\left(-\mathrm{CONH}_{2} \rightarrow-\mathrm{CN}\right)$ and the reduction of nitro group to amino group $\left(-\mathrm{NO}_{2} \rightarrow-\mathrm{NH}_{2}\right)$ in the course of synthesis.

Acknowledgements. The author wishes to express his sincere thanks to Miss $\mathrm{K}$. Michi and Mr. S. Emoto who have been associated with him on this work, and it is only their splendid cooperative spirit that has made this work possible.

He also acknowledges with gratitude his indebtedness to Prof. T. Yabuta and Prof. K. Goto for the valuable advice, to Dr. S. Ohdake and Mr. M. Kamada for the generous donation of this vitamin hydrochloride preparations, and to Mr. T. Shoda, the president of the Nisshin Flour Millings Co., for the financial assistance.

Lastly, special thanks are due to Dr. W. Nakahara, and other members of the Scientific Research Institute (formerly the Institute of Physical and Chemical Research), who have been kind enough to show keen interest in this work.

\section{REFERENCES}

1. a) Snell, E. E. et al: See "The Vitamin $B_{6}$ Group, III-V". J. Biol. Chem., 159, 475, 491, 1945 : J. Am. Chem. Soc., 67, 194, 1945.

b) Lichstein, H.C., Gunsalus, I.C. and Umbreit, W.W.: See "Function of the Vitamin B ${ }_{6}$ Group" J. Biol. Chem., 161, 311, 1945.

2. a) Kuhn, R., and Wendt, G.: “Über das antidermatitische Vitamin der Hefe". Ber., 71, 780, 1938.

b) Kuhn, R., and Wendt, G.: “Über das aus Reiskleie und Hefe isolierte Adermin (Vitamin $B_{6}$ ). Ber., 71, 1118. 1938.

c) Kuhn, R., and Wendt, G.: “Über die funktionellen Gruppen des Adermins". Ber., 71, 1534, 1938.

d) Kuhn, R., and Wendt, G.: “Über den oxydativen Abbau des Adermins". Ber., 72, 305, 1939.

e) Kuhn, R., Andersag, H., Wendt, G.: "Vitamin $B_{6}$, ein Derivat des 3-oxy-pyridins". Ber., 72 , 309, 1939.

f) Kuhn, R., Wendt, G., and Westphal, K.: “Die Konstitution des Adermins”. Ber., 72, 310, 1939. 
g) Kuhn, R. and Wendt, G.: “Rückverwandlung von Adermin-methyläther in Adermin". Ber., 72, 311, 1939.

h) Kuhn, R. and Löw, I.: “Über eine sparifische Farbereaktion des Adermins"., Ber., 72, 1453, 1939.

i) Kuhn, R., Wastphal, K., Wendt, G., and Westphal, O.: "Synthese des Adermins". Naturwiss., 27, 469. 1939.

3. a) Keresztesy, J. C., and Stevens, J. R.: “Crystalline Vitamin $B_{6}$ ”. Proc. Expt. Biol. Med., 64. 1938.

b) Lepkovsky, S.: “Crystalline Factor I". Science, 87, 169, 1938.

c) Lepkovsky, S.: "The Isolation of Factor I in Crystalline Form". J. Biol. Chem., 124, 125, 1938.

d) György, P.: “Crystalline Vitamin B". J. Am. Chem. Soc., 60, 984, 1938.

e) Keresztesy, J. C. and Stevens, J. R.: "Vitamin B ${ }_{6}$ ". J. Am. Chem. Soc., 60, 1268. 1938.

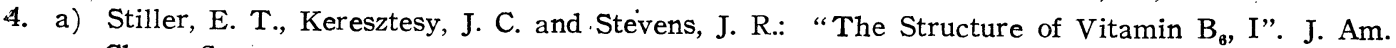
Chem. Soc., 61, 1237, 1939.

b) Harris, S. A., Stiller, E. T. and Folkers, K.: “The Structure of Vitamin B, II". J. Am. Chem. Soc., 61, 1242, 1939.

c) Harris, S. A., and Folkers, K.: "Synthesis of Vitamin $B_{8}$ ". J. Am. Chem. Soc., 61, 1245. 1939.

d) Harris, S. A., and Folkers, K.: "Synthesis of Vitamin $\mathrm{B}_{6}$, II". J. Am. Chem. Soc., 61, 3307, 1939.

e) Harris, S. A., Webb, T. J., and Folkers, K.: "Chemistry of Vitamin B. B $_{8}$, Tautomerism". J. Am. Chem. Soc., 62, 3198, 1940.

f) Harris, S. A.: "Chemistry of Vitamin $B_{6}$, II, Reactions and Derivatives". J. Am. Chem. Soc., 62, 3203, 1940.

g) Harris, S. A., and Wilson, A. N.: "Chemistry of Vitamin $B_{6}$, III, A Homolog of Vitamin $B_{6}$ ". J. Am. Chem. Soc., 63, 3360, 1941.

h) Harris, S. A.: "Chemistry of Vitamin $B_{6}, I V$, Reaction in solutions at elevated Temperature". J. Am. Chem. Soc., 63, 3363, 1941.

5. a) Ichiba, A., and Michi, K.: “Crystalline Vitamin $B_{8}$ ". Sc. Pap. Í.P.C.R., 34, 623, 1938.

b) Ichiba, A., and Michi, K.: "A Note on the Chemistry of Vitamin $B_{6}$ ". Sc. Pap. I.P.C.R., 34, 1014, 1938.

c) Ichiba, A., and Michi, K.: “On the Chemistry of Vitamin $B_{6}$ ”. Sc. Pap. I.P.C.R., 35, 73, 1938.

d) Ichiba, A., and Michi, K.: "On the Chemistry of Vitamin $B_{6}$ (continued)". Sc. Pap, I.P.C.R., $36,1,1939$.

e) Ichiba, A., and Michi, K.: "On the Chemistry of Vitamin $B_{6}$ (continued), Synthesis of 2-methyl3-methoxy pyridine dicarboxylic acid (4, 5)". Sc. Pap. I.P.C. R., 36, 173, 1939.

f) Ichiba, A., and Emoto, S.: "Synthesis of 2-methyl-3-hydroxypyridine dicarboxylic acid $(4,5)$ ". Sc. Pap. I.P.C.R., 38, 347, 1941.

g) Ichiba, A., Michi, K. and Emoto, S.: “A Note on the Synthesis of 2-methyl-3-methoxycinchomeronic acid diamide". Sc. Pap. I.P.C. R., 39, 126, 1941.

h) Ichiba, A., and Emoto, S.: "Synthesis of 2-methyl-4, 5-di (hydroxymethyl)-pyridine". Sc. Pap. I.P.C.R., 39, 131, 1941.

i) Ichiba, A., and Emoto, S.: "Synthesis of Vitamin $B_{6}$ ". Jap. Pat., No. 159890, (issue, Aug., 1943: application, Aug., 1942).

6. on Isolation,

a) Emerson and Evans: J. Biol. Chem., 124, 377, 1938,

b) Dalmer: Z. Angew. Chem., 51, 174, 1938.

c) Schoor: E. Mercks Jahresber., 52, 7, 1936.

d) Matsukawa, I.: Yakugaku-Kaishi, 60, 551, 1940.

e) Ohodake, S.: Proc. Imper. Acad. Japan, 7, 780, 1931.

7. Ohodake, S.:

"Isolation of Oryzanin Crystals (antineuritic Vitamin) from Rice Polishings".

Proc. Imper. Acad. Japan, 7, 102. 1931. (J. Agr. Chem. Soc. Japan. 7. 775. 1931.).

8. Williams, R. R.: Vitamins from the Sandpoint' of Structural Chemistry". J. Ind. Eng. Chem.,

9. Bardham, J. C.: "The Mechanism of the Cyanoacetamide and Cyanoacetic Ester Condensations". 
J. Chem. Soc., 2223, 1929.

10. Simonsen, J. L., and Nyak, M.: "Condensation of Ethyl Cyanoacetate and Acetylacetone". J. Chem. Soc., 792, 1915.

11. Mowat, J. H., Pilgrim, F. J., and Carlson, G H.: "Synthesis of Vitamin B,". J. Am. Chem. Soc., 65, 954, 1943. (C.. A., 37, 4399, 1943.): (U. S. Pat. No. 2310167, 1943).

\title{
STUDIES ON DENGUE FEVER I. STUDIES ON DENGUE VIRUS AND IMMUNITY.
}

\author{
By NobUtaro ISHII \\ National Institute of Health of Japan, Tokyo \\ (This report is a summary of our studies during the period of 1942-1944)
}

\section{E. ImMunOlOGic Tests}

\section{Neutralization test}

The neutralization tests of the convalescent sera of patients, infected with mouse virus, against mouse virus or human dengue virus, and the neutralization tests of the rabbit sera, immunized with mouse virus, against mouse virus, were carried out.

a. Patient serum, infected with mouse virus, against mouse virus

The convalescent sera of three persons infected with mouse virus of about twenty serial passages, and of four persons infected with rabbit eye fluid and mouse brain of the primary infection tests, were used for the neutralization tests against mouse virus.

Equal doses of the convalescent serum and the emulsion of infected mouse brain were mixed and kept at room temperature for thirty minutes. Thirty cubic millimeter of this mixture were injected intracerebrally into mice. As shown in table 5, the neutralizing substance was produced in human body by the animal virus, and both $\mathrm{K}$-strain and $\mathrm{M}$-strain were demonstrated to exhibit the same behavior.

Table 5

\begin{tabular}{|c|c|c|c|c|c|c|c|c|}
\hline \multirow[b]{2}{*}{ Virus } & \multicolumn{3}{|c|}{$\begin{array}{l}\text { Convalescent serum } \\
\text { caused by mouse virus }\end{array}$} & \multicolumn{4}{|c|}{$\begin{array}{l}\text { Convalescent serum } \\
\text { caused by mouse and rabbit virus }\end{array}$} & \multirow[b]{2}{*}{ Control } \\
\hline & $\begin{array}{l}\text { INOUE } \\
\text { (K-st) }\end{array}$ & $\begin{array}{l}\text { SHIMA } \\
\text { BUKURO } \\
(\mathrm{K} \cdot \mathrm{st})\end{array}$ & $\begin{array}{c}\text { SHıRAISHI } \\
\text { (M-st) }\end{array}$ & $\begin{array}{c}\text { YAJIMA } \\
\text { (K-st) }\end{array}$ & $\begin{array}{l}\text { MITOMA } \\
\quad(\mathrm{K} \text {-st })\end{array}$ & $\begin{array}{l}\text { ISHII } \\
\text { (M-st) }\end{array}$ & $\begin{array}{l}\text { ICHO } \\
\text { (M-st) }\end{array}$ & \\
\hline $\begin{array}{l}\text { K-st. } \\
\text { M-st. }\end{array}$ & W & H & H & $\begin{array}{l}\text { H } \\
H\end{array}$ & $H$ & $\begin{array}{l}H \\
H\end{array}$ & $\begin{array}{l}\mathrm{HI} \\
\mathrm{H}\end{array}$ & - \\
\hline $\begin{array}{r}+\ldots \ldots \\
-\ldots \ldots \\
\text { K-stra } \\
\text { M-stra }\end{array}$ & $\begin{array}{l}\text { atrali } \\
\text { neu } \\
\ldots \ldots \ldots \\
\ldots \ldots \ldots\end{array}$ & $\begin{array}{l}\text { zed } \\
\text { is passed } \\
\text { is passed }\end{array}$ & through & bbits & & & & \\
\hline
\end{tabular}

